\title{
Soil aggregation according to the dynamics of carbon and nitrogen in soil under different cropping systems
}

\author{
Getulio de Freitas Seben Junior( ${ }^{(1)}$, José Eduardo Corá(2) and Rattan Lal(3)
}

\begin{abstract}
(1)Universidade do Estado de Mato Grosso, Avenida Perimetral Rogério Silva, no 4.930, Jardim Flamboyant, CEP 78580-000 Alta Floresta, MT, Brazil. E-mail: getulioseben@unemat.br (2)Universidade Estadual Paulista, Campus de Jaboticabal, Via de Acesso Prof. Paulo Donato Castellane, s/no, CEP 14884-900 Jaboticabal, SP, Brazil. E-mail: cora@fcav.unesp.br ${ }^{(3)}$ Ohio State University, 2021 Coffey Road, Columbus, OH, 43210, USA. E-mail: lal.1@osu.edu
\end{abstract}

\begin{abstract}
The objective of this work was to evaluate total soil carbon and nitrogen, as well as their contents in particulate and mineral-associated $\mathrm{C}$ fractions; to determine $\mathrm{C}$ stock and sequestration rates in the soil; and to verify the effect of $\mathrm{C}$ and $\mathrm{N}$ contents on soil aggregation, using different crop rotations and crop sequences under no-tillage. The study was carried out for nine years in a clayey Oxisol. The treatments consisted of different cropping systems formed by the combination of three summer crops (cropped until March) - corn (Zea mays) monocropping, soybean (Glycine max) monocropping, and soybean/corn rotation - and seven second crops (crop successions). Soil samples were taken at the $0.00-0.10-\mathrm{m}$ layer for physical fractionation of $\mathrm{C}$ and $\mathrm{N}$, and to determine soil aggregation by the wet method. Soybean monocropping increased $\mathrm{C}$ and $\mathrm{N}$ in particulate $\mathrm{C}$ fraction, while the crop systems with corn monocropping $\mathrm{x}$ pigeon pea (Cajanus cajan), corn monocropping $\mathrm{x}$ sun hemp (Crotalaria juncea), and soybean monocropping $\mathrm{x}$ corn as a crop succession increased total $\mathrm{C}$ in the soil. Greater rates of soil $\mathrm{C}$ sequestration were observed with soybean/corn rotation and with soybean monocropping, as well as with sun hemp as a second crop. The increase in total $\mathrm{N}$ increases soil C stock. Soil aggregation was most affected at particulate $\mathrm{C}$ fraction. Increases in soil N promote C addition to particulate fraction and enhance soil aggregation.
\end{abstract}

Index terms: carbon sequestration, carbon stocks, cover crops, crop rotation, soil aggregates, soil organic matter.

\section{Agregação do solo de acordo com a dinâmica de carbono e nitrogênio em solo sob diferentes sistemas de cultivo}

Resumo - O objetivo deste trabalho foi avaliar o conteúdo total de carbono e de nitrogênio no solo, bem como seu conteúdo nas frações carbono particulado e associado a minerais; determinar o estoque de $\mathrm{C}$ e suas taxas de sequestro no solo; e verificar o efeito dos conteúdos de $\mathrm{C}$ e $\mathrm{N}$ sobre a agregação do solo, com diferentes rotações e sequências de culturas, sob plantio direto. O estudo foi realizado por nove anos, em Latossolo Vermelho argiloso. Os tratamentos consistiram de diferentes sistemas de cultivo formados pela combinação de três cultivos de verão (cultivados até março) - monocultura de milho (Zea mays), monocultura de soja (Glycine max) e rotação soja/milho - e sete cultivos de sucessão. Amostras de solo foram retiradas da camada de $0,00-0,10 \mathrm{~m}$ para fracionamento físico de $\mathrm{C}$ e $\mathrm{N}$, e para determinar a agregação do solo via úmida. A monocultura de soja promoveu aumento de $\mathrm{C}$ e $\mathrm{N}$ na fração $\mathrm{C}$ particulado, enquanto os sistemas com monocultivo de milho x feijão-guandu (Cajanus cajan), monocultivo de milho x crotalária (Crotalaria juncea) e monocultivo de soja x milho em sucessão incrementaram $\mathrm{C}$ total no solo. Os maiores sequestros de $\mathrm{C}$ no solo foram verificados com a rotação soja/milho e soja em monocultivo, bem como com a crotalária em sucessão no inverno. $\mathrm{O}$ aumento do conteúdo total de $\mathrm{N}$ aumenta o estoque de $\mathrm{C}$ no solo. A agregação do solo foi mais influenciada pela fração $\mathrm{C}$ particulado. Aumentos no conteúdo de $\mathrm{N}$ no solo promovem a adição de C na fração particulada e aumentam a agregação do solo.

Termos para indexação: sequestro de carbono, estoque de carbono, plantas de cobertura, rotação de culturas, agregados do solo, matéria orgânica do solo.

\section{Introduction}

Agricultural soils of the tropical regions contain less soil carbon than their capacity to store, because of the high soil organic matter mineralization (Lal,
2005). In these regions, Oxisols predominate, with up to $150 \mathrm{Pg} \mathrm{C}$ stored in the topsoil layer of $0.20 \mathrm{~m}$ (Lal, 2012). Therefore, the evaluation of the impact of crop sequences on carbon and nitrogen dynamics in Oxisols

Pesq. agropec. bras., Brasília, v.51, n.9, p.1652-1659, set. 2016

DOI: 10.1590/S0100-204X2016000900065 
could be a means to mitigate $\mathrm{CO}_{2}$ and $\mathrm{N}_{2} \mathrm{O}$ emissions, with repercussions on climate and on soil quality (Sá \& Lal, 2009).

The no-tillage system is a conservationist practice that can minimize losses and increase carbon in tropical soils, from $0.35 \mathrm{Mg} \mathrm{ha}^{-1}$ per year (Bayer et al., 2006) to $1.30 \mathrm{Mg} \mathrm{ha}^{-1}$ per year, which can be intensified with crop rotation (Sá et al., 2013). Soil aggregation and carbon and nitrogen contents are attributes very sensible to soil management and also affected by crop type. Legumes are often used in conservationist soil management systems due to their capacity to biologically fix high quantities of nitrogen and can contribute to soil carbon addition at rates of $0.88 \mathrm{Mg} \mathrm{ha}^{-1}$ per year (Diekow et al., 2005). These additions are commonly linked to increases in soil aggregation, which, in turn, protect soil carbon against microbial decomposition (Tisdall \& Oades, 1982; Conceição et al., 2013). Grasses are mainly used in conservationist systems due to their high aboveground biomass yield, with greater $\mathrm{C}: \mathrm{N}$ ratio (Marcelo et al., 2012a), and to their dense root system, which is associated with intense microbial activity. These croptype features can increase soil carbon at a rate of 0.71 $\mathrm{Mg} \mathrm{ha}^{-1}$ per year (Calegari et al., 2008; Martins et al., 2012a).

However, the effects of crop rotation systems and of crop sequences are far from being completely understood. This is unfortunate, since soil conservation should not be treated exclusively as a function of the effects of legumes and grasses on its $\mathrm{C}$ and $\mathrm{N}$ dynamics (Silva et al., 2010).

Soil aggregate stability and diameter are closely related with soil carbon and nitrogen contents (Tisdall \& Oades, 1982; Conceição et al., 2013). Moreover, the physical fractionation of soil organic matter into particulate carbon and mineral-associated carbon may greatly contribute to the understanding of $\mathrm{C}$ and $\mathrm{N}$ dynamics and of soil aggregation (Diekow et al., 2005). Carbon in particulate fraction represents the lowest carbon stock in Oxisols, although it is the most active fraction and is highly susceptible to soil management and cropping systems (Diekow et al., 2005; Sá \& Lal, 2009; Conceição et al., 2013), whereas mineral-associated carbon fraction is the greatest and most stable carbon stock in the soil (Lal, 2005).

The great chemical affinity of $\mathrm{Fe}$ and $\mathrm{Al}$ oxyhydroxides with soil carbon optimizes aggregation in Oxisols, with the formation of organomineral aggregates (Tisdall \& Oades, 1982). The union of these highly stable aggregates originates microaggregates, with diameter size smaller than $250 \mu \mathrm{m}$, commonly associated with carbon sequestration in Oxisols (Tisdall \& Oades, 1982; Conceição et al., 2013). Furthermore, microaggregates are held together by roots, fungi hyphae, and polysaccharides to form macroaggregates with diameter size greater than $250 \mu \mathrm{m}$, which are less stable and more sensible to changes in land use and soil management (Tisdall \& Oades, 1982). These macroaggregates can also be formed around particulate carbon, protecting it against microbial degradation (Lal, 2005). However, inside macroaggregates, particulate carbon may be found fragmented into smaller particles, which bind themselves to soil mineral particles to form microaggregates (Tisdall \& Oades, 1982).

The objective of this work was to evaluate total soil carbon and nitrogen, as well as their contents in particulate and mineral-associated $\mathrm{C}$ fractions; to determine $\mathrm{C}$ stock and sequestration rates in the soil; and to verify the effect of $\mathrm{C}$ and $\mathrm{N}$ contents on soil aggregation, using different crop rotations and crop sequences under a no-tillage system.

\section{Materials and Methods}

The study was carried out in the municipality of Jaboticabal, in the state of São Paulo, Brazil (21 ${ }^{\circ} 14^{\prime}$ S, $48^{\circ} 17^{\prime} \mathrm{W}$, at $550 \mathrm{~m}$ of altitude). The experimental site is in a tropical/megathermal zone, with Aw climate, according to Köppen's classification, with dry and warm winters, and wet and hot summers. The mean annual temperature is $22^{\circ} \mathrm{C}$, with 1,430 $\mathrm{mm}$ annual rainfall, considering an average of 30 years. The soil of the experimental area is a clayey Latossolo Vermelho eutrófico (Oxisol) according to the Brazilian soil classification (Santos et al., 2013). At the $0.00-0.10-\mathrm{m}$ soil layer, the contents of clay, silt, and sand were, respectively, 556, 63, and $381 \mathrm{~g} \mathrm{~kg}^{-1}$. Some mineralogical properties of this soil have been previously described in Martins et al. (2009).

Before the experiment, in 2002, the soil was prepared with subsoiling down to $0.40-\mathrm{m}$ depth; and plowing and disking were used to incorporate $1.5 \mathrm{Mg} \mathrm{ha}^{-1}$ of lime to the soil. In June 2005, $1.0 \mathrm{Mg} \mathrm{ha}^{-1}$ lime was applied to soil surface with no incorporation, in order 
to increase base saturation up to $65 \%$ (Marcelo et al., 2009).

The experiment was conducted using a randomized complete block design, with strip plots and three replicates. Each block had 21 plots, consisting of three summer cropping systems combined with seven crop sequences (Figure 1). The summer crops were grown between November and March, and were repeated every year in the same plots. They formed the following cropping systems: corn (Zea mays L.) monocropping; soybean [Glycine max (L.) Merr.] monocropping; and soybean/corn rotation. Second crops were sown in March and were also repeated every year in the same plots, consisting of the following crop sequences (second crops): corn, sunflower (Helianthus annuus L.), oilseed radish (Raphanus sativus L.), pearl millet [Pennisetum americanum (L.) K.Schum], pigeon pea [Cajanus cajan (L.) Millsp.], grain sorghum [Sorghum bicolor (L.) Moench], and sun hemp (Crotalaria juncea L.).

Soil fertilization for all second crops consisted of $200 \mathrm{~kg} \mathrm{ha}^{-1} \mathrm{~N}-\mathrm{P}_{2} \mathrm{O}_{5}-\mathrm{K}_{2} \mathrm{O} 8-20-20$, applied at sowing. For summer crops, the base fertilization was performed according to the soil chemical attributes, determined on the soil test of the previous growing season, which can be found in Marcelo et al. (2009).

Soil sampling was done after nine years from the experiment establishment, in October 2011, before sowing the summer crops of the next growing season (2011/2012). In each plot, three undisturbed soil samples $(5.0-\mathrm{cm}$ diameter $\times 5.0-\mathrm{cm}$ height) were taken at the $0.00-0.10-\mathrm{m}$ soil layer. Additionally, 20 disturbed soil samples were taken randomly from each plot, to perform a composite sample, at the $0.00-0.10-\mathrm{m}$ layer. Each composite sample was divided into two portions: the first was used to select soil aggregates with diameter between 6.30 and $4.00 \mathrm{~mm}$, with the same moisture content in the field; and the second portion was air-dried during 48 hours and ground to pass through a $2-\mathrm{mm}$ sieve.

To determine soil aggregate mean weight diameter, a $25 \mathrm{-g}$ portion of soil aggregates, with diameters of $6.30-4.00 \mathrm{~mm}$, was transferred to a set of sieves in decreasing order of mesh sizes: 4.00, 2.00, 1.00, $0.50,0.25$, and $0.125 \mathrm{~mm}$. The sieve set was directly immersed - with the aggregates without pre-wetting in water, in an apparatus for vertical oscillation (Yoder, 1936), during $15 \mathrm{~min}$, adjusted to 31 cycles per min.

From the second portion, $30 \mathrm{~g}$ were used for a particle-size fractionation. This sample was placed in a 200-mL plastic bottle with a sodium hexametaphosphate solution $\left(5 \mathrm{~g} \mathrm{~L}^{-1}\right)$, and three agate balls (5-mm diameter) were used to improve soil mechanical dispersion. The content was shook overnight, for 16 hours, in a horizontal shaker, at the frequency of $50 \mathrm{rpm}$. The sample was passed through a $250-\mu \mathrm{m}$ sieve placed above another one of $53 \mu \mathrm{m}$. Fractions were selected as in Koutika et al. (2001): from 2,000 to $250 \mu \mathrm{m}$, medium particulate carbon; from 250 to $53 \mu \mathrm{m}$, fine particulate carbon; and $<53 \mu \mathrm{m}$, mineral-associated carbon. The remaining material in each class was washed, ovendried at $50^{\circ} \mathrm{C}$, weighed, and grounded to pass a $105-\mu \mathrm{m}$ mesh sieve, for carbon and nitrogen determination.
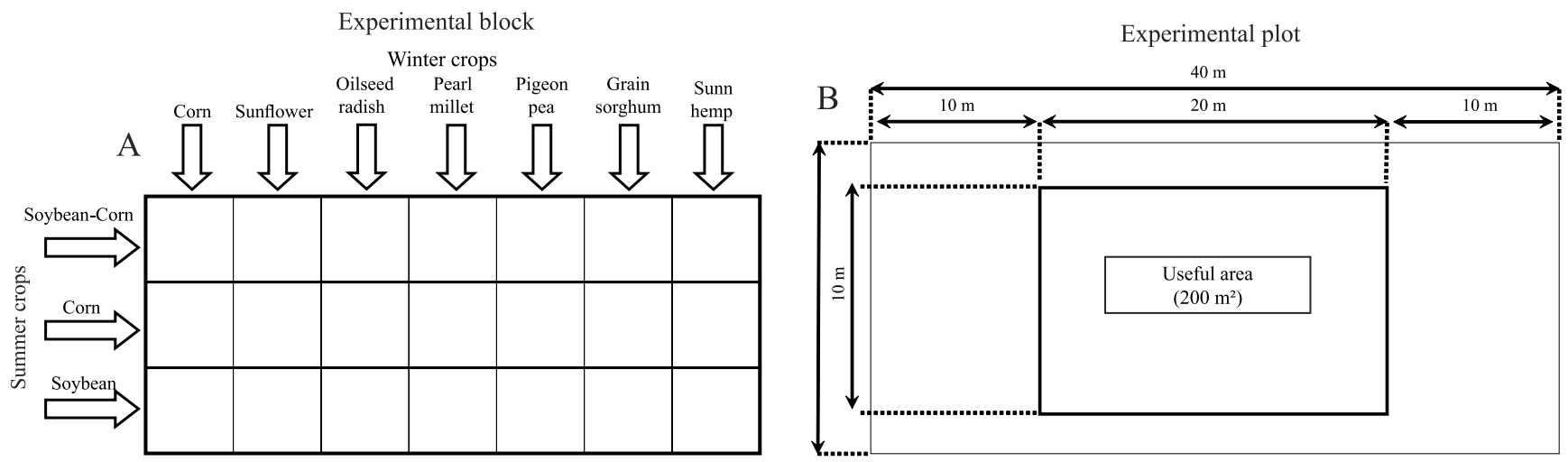

Figure 1. Experimental sketch showing: A, experimental blocks (replicates); and B, plots. The experiment was carried out in randomized complete blocks, arranged in strip plots, with 21 treatments and three replicates. Soybean, Glycine max; corn, Zea mays; sunflower, Helianthus annuus; oilseed radish, Raphanus sativus; pearl millet, Pennisetum americanum; pigeon pea, Cajanus cajan; grain sorghum, Sorghum bicolor; and sun hemp, Crotalaria juncea. 
Another $4 \mathrm{~g}$ of the bulk soil were oven-dried at $50^{\circ} \mathrm{C}$ and ground to pass the same $105-\mu \mathrm{m}$ mesh sieve. Portions between 0.275 to $0.300 \mathrm{~g}$, from each sample, were weighed to determine total carbon and total nitrogen concentrations, using dry combustion at $900^{\circ} \mathrm{C}$ in a carbon and nitrogen analyzer.

Soil density was determined (Grossman \& Reinsch, 2002) to calculate total carbon stock by equivalent soil mass (Ellert \& Bettany, 1995). In the present study, native forest soil properties, such as total carbon concentration $\left(30.16 \mathrm{~g} \mathrm{~kg}^{-1}\right)$ and soil bulk density $(0.92$ $\mathrm{kg} \mathrm{dm}^{-3}$ ), were used as a baseline to analyze total carbon stocks in the treatments. In addition, the rate of carbon sequestration was determined by the difference between actual $\mathrm{C}$ contents minus the $\mathrm{C}$ content of $11.02 \mathrm{~g} \mathrm{~kg}^{-1}$ - obtained before the beginning of the experiment in 2002 -, divided by nine years.

The obtained data were subjected to the analysis of variance using the F-test, and means were compared by Tukey's test, at 5\% probability. Also, Pearson's correlation was used to evaluate the relationship of total nitrogen and aggregate mean weight diameter with total carbon and carbon contents at medium particulate, fine particulate, and mineral-associated fractions.

\section{Results and Discussion}

Soybean monocropping increased soil carbon and nitrogen contents in the medium particulate carbon fraction, when compared with corn monocropping (Table 1). However, neither summer crops nor second crops affected the contents of carbon and nitrogen in fine particulate and mineral-associated fractions. The increases in carbon and nitrogen by soybean monocropping may be attributed to the low $\mathrm{C}: \mathrm{N}$ ratio of it residues in comparison with those of corn, which contributes to quickly adding carbon and nitrogen into the medium particulate fraction. The continuous input of crop residues on the soil, under no-tillage, is essential to carbon addition in particulate carbon fraction, which is composed of fresh residues (Sá \& Lal, 2009).

Within monocropping, carbon and nitrogen contents showed the lowest values with the second crops corn, sorghum, and sunflower (Table 2). This may

Table 1. Soil contents of carbon and nitrogen, as well as C:N ratio, determined in different carbon fractions and in bulk soil, rate of carbon sequestration, and mean weight diameter (MWD) of an Oxisol under three cropping systems combined with seven crop sequences, under no-tillage ${ }^{(1)}$.

\begin{tabular}{|c|c|c|c|c|c|c|c|c|c|c|c|c|c|c|}
\hline \multirow[t]{3}{*}{ Treatment $^{(2)}$} & \multicolumn{3}{|c|}{$\begin{array}{l}\text { Medium particulate carbon } \\
\text { fraction }\end{array}$} & \multicolumn{3}{|c|}{$\begin{array}{c}\text { Fine particulate carbon } \\
\text { fraction }\end{array}$} & \multicolumn{3}{|c|}{ Mineral-associated carbon } & \multicolumn{3}{|c|}{ Bulk soil } & \multirow{3}{*}{$\begin{array}{c}\text { Rate of } \mathrm{C} \\
\text { sequestration } \\
\text { ( } \mathrm{Mg} \mathrm{ha}^{-1} \mathrm{C} \\
\text { per year) }\end{array}$} & \multirow{3}{*}{$\begin{array}{l}\text { MWD } \\
(\mathrm{mm})\end{array}$} \\
\hline & $\mathrm{C}$ & $\mathrm{N}$ & $\mathrm{C}: \mathrm{N}$ & $\mathrm{C}$ & $\mathrm{N}$ & $\mathrm{C}: \mathrm{N}$ & $\mathrm{C}$ & $\mathrm{N}$ & $\mathrm{C}: \mathrm{N}$ & $\mathrm{C}$ & $\mathrm{N}$ & $\mathrm{C}: \mathrm{N}$ & & \\
\hline & \multicolumn{2}{|c|}{------( $\left(\mathrm{g} \mathrm{dag}^{-1}\right)------$} & & \multicolumn{2}{|c|}{-------( $\left(\mathrm{g} \mathrm{dag}^{-1}\right)------$} & & \multicolumn{2}{|c|}{------( $\left(\mathrm{g} \mathrm{dag}^{-1}\right)------$} & & \multicolumn{3}{|c|}{-------- $\left(\mathrm{g} \mathrm{kg}^{-1}\right)$--------- } & & \\
\hline \multicolumn{15}{|l|}{ Summer crops } \\
\hline Soybean-corn & $16.74 \mathrm{ab}$ & $11.75 \mathrm{ab}$ & $18.05 \mathrm{ab}$ & 32.52 & 29.65 & 13.74 & 50.74 & 58.60 & 10.82 & $17.66 \mathrm{a}$ & 1.51 & 11.70 & $0.68 \mathrm{a}$ & $2.99 \mathrm{a}$ \\
\hline Corn-corn & $13.72 b$ & $9.71 b$ & $18.92 \mathrm{a}$ & 29.92 & 26.67 & 13.93 & 56.35 & 63.62 & 11.23 & $16.23 b$ & 1.40 & 11.59 & $0.53 b$ & $2.94 \mathrm{ab}$ \\
\hline Soybean-soybean & $19.18 \mathrm{a}$ & $14.60 \mathrm{a}$ & $13.21 \mathrm{~b}$ & 32.15 & 29.77 & 10.72 & 48.67 & 55.62 & 15.59 & $17.72 \mathrm{a}$ & 1.51 & 11.74 & $0.69 \mathrm{a}$ & $2.80 \mathrm{~b}$ \\
\hline F-test & $11.21^{*}$ & $11.10^{*}$ & $5.81^{*}$ & $1.17^{\mathrm{ns}}$ & $1.97^{\mathrm{ns}}$ & $67.80^{\text {ns }}$ & $4.41^{\mathrm{ns}}$ & $5.06^{\mathrm{ns}}$ & $136.91^{\mathrm{ns}}$ & $6.25^{*}$ & $2.73^{\text {ns }}$ & $0.01^{\mathrm{ns}}$ & $6.38^{*}$ & $8.09^{*}$ \\
\hline$\overline{C V(\%)}$ & 22.6 & 28.1 & 35.0 & 18.9 & 20.0 & 7.8 & 16.7 & 13.9 & 8.3 & 9.0 & 12.9 & 4.0 & 24.7 & 23.6 \\
\hline \multicolumn{15}{|l|}{ Second crops } \\
\hline Corn & 16.05 & 11.53 & 16.73 & 30.53 & 27.48 & 13.01 & 53.42 & 61.00 & 12.87 & $16.89 \mathrm{ab}$ & 1.46 & 11.57 & $0.60 \mathrm{ab}$ & $2.58 \mathrm{~b}$ \\
\hline Sunflower & 16.45 & 11.70 & 16.54 & 30.02 & 27.32 & 12.99 & 53.53 & 60.98 & 12.52 & $16.60 \mathrm{ab}$ & 1.41 & 11.77 & $0.57 \mathrm{ab}$ & $1.95 \mathrm{~b}$ \\
\hline Oilseed radish & 15.17 & 10.60 & 16.88 & 30.87 & 28.59 & 12.39 & 53.96 & 60.81 & 12.40 & $16.33 b$ & 1.39 & 11.75 & $0.54 b$ & $2.46 \mathrm{~b}$ \\
\hline Pearl millet & 16.95 & 12.47 & 16.69 & 31.50 & 28.80 & 12.71 & 51.55 & 58.73 & 12.80 & $16.90 \mathrm{ab}$ & 1.48 & 11.42 & $0.60 \mathrm{ab}$ & $2.74 \mathrm{ab}$ \\
\hline Pigeon pea & 15.92 & 11.67 & 16.15 & 32.64 & 29.53 & 12.75 & 51.43 & 58.79 & 12.59 & $17.88 \mathrm{ab}$ & 1.51 & 11.84 & $0.70 \mathrm{ab}$ & $2.42 b$ \\
\hline Grain sorghum & 17.78 & 13.60 & 16.01 & 34.18 & 30.83 & 12.72 & 48.05 & 55.56 & 11.67 & $17.08 \mathrm{ab}$ & 1.47 & 11.62 & $0.62 \mathrm{ab}$ & $3.35 \mathrm{a}$ \\
\hline Sun hemp & 17.50 & 12.57 & 18.07 & 30.99 & 28.35 & 13.02 & 51.51 & 59.08 & 12.97 & $18.73 \mathrm{a}$ & 1.61 & 11.63 & $0.79 \mathrm{a}$ & $2.74 \mathrm{ab}$ \\
\hline F-test & $1.34^{\mathrm{ns}}$ & $1.87^{\mathrm{ns}}$ & $0.80^{\text {ns }}$ & $1.13^{\text {ns }}$ & $0.82^{\mathrm{ns}}$ & $1.67^{\text {ns }}$ & $1.51^{\mathrm{ns}}$ & $1.36^{\mathrm{ns}}$ & $1.45^{\text {ns }}$ & $2.48^{*}$ & $2.28^{\text {ns }}$ & $0.52^{\text {ns }}$ & $2.49^{*}$ & $5.38^{*}$ \\
\hline$\overline{C V(\%)}$ & 14.5 & 17.5 & 13.4 & 12.8 & 14.0 & 4.2 & 9.5 & 8.4 & 8.7 & 9.2 & 9.8 & 3.4 & 25.4 & 20.9 \\
\hline \multicolumn{15}{|l|}{ SxW interaction } \\
\hline F-test & $0.57^{\mathrm{ns}}$ & $0.52^{\mathrm{ns}}$ & $0.91^{\mathrm{ns}}$ & $1.30^{\mathrm{ns}}$ & $1.27^{\mathrm{ns}}$ & $0.91^{\mathrm{ns}}$ & $0.78^{\mathrm{ns}}$ & $1.01^{\mathrm{ns}}$ & $1.0^{\mathrm{ns}}$ & $6.11^{*}$ & $3.90^{*}$ & $2.86^{\mathrm{ns}}$ & $6.21^{\mathrm{ns}}$ & $0.52^{\mathrm{ns}}$ \\
\hline CV (\%) & 22.9 & 27.1 & 14.4 & 11.9 & 13.0 & 5.8 & 10.3 & 8.5 & 9.7 & 7.3 & 8.8 & 2.8 & 20.0 & 14.8 \\
\hline
\end{tabular}

${ }^{(1)}$ Means followed by equal letters do not differ by Tukey's test, at 5\% probability. (2)Soybean, Glycine max; corn, Zea mays; sunflower, Helianthus annuus; oilseed radish, Raphanus sativus; pearl millet, Pennisetum americanum; pigeon pea, Cajanus cajan; grain sorghum, Sorghum bicolor; and sun hemp, Crotalaria juncea. ${ }^{*}$ Significant at $5 \%$ probability. 
be explained by the greater recalcitrance of pigeon pea and sun hemp residues and by the fact that the former crops are commonly cultivated for grain yield, exporting, respectively, 40.85, 44.90, and $37.10 \mathrm{~kg}$ ha $^{-1} \mathrm{~N}$ (Marcelo et al., 2012a, 2012b). Besides, pigeon pea and sun hemp fix, annually, 23.5 and $19.5 \mathrm{~g} \mathrm{~kg}^{-1}$ $\mathrm{N}$, respectively (Marcelo et al., 2012a), which may contribute to the accumulation of soil carbon and nitrogen (Bayer \& Mielniczuk, 2008). According to Seo et al. (2006), crops recover $15 \%$ of the total $N$ from labeled legume residue, in the first year; and another $55 \%$ are recovered from the soil organic $\mathrm{N}$ fraction.

Within soybean monocropping, soil under corn, as a crop sequence, had its carbon content increased, in comparison with soil under oilseed radish (Table 2). Plots cultivated with corn as a second crop had higher plant biomass on soil surface $\left(2.7 \mathrm{Mg} \mathrm{ha}^{-1}\right)$, with higher nitrogen content $\left(13.10 \mathrm{Mg} \mathrm{ha}^{-1} \mathrm{~N}\right.$ per year) than that with oilseed radish $\left(0.3\right.$ and $0.9 \mathrm{Mg} \mathrm{ha}^{-1} \mathrm{~N}$ per year, respectively). Considering that the highest $\mathrm{NO}_{3}{ }^{-}$ contents from oilseed radish residues become available in the first 54 days after plant harvesting (Heinzmann, 1985), this crop may not contribute significantly to nitrogen availability for the summer crop, contrary to what has been observed with corn, which can release $\mathrm{NO}_{3}{ }^{-}$during soybean growth.

In general, soil cultivated with corn as a second crop had higher carbon and nitrogen contents, and, among summer cropping systems, soybean monocropping raised $\mathrm{C}$ and $\mathrm{N}$, when compared with corn monocropping, at the $0.00-0.10-\mathrm{m}$ soil layer (Table 2). Amado et al. (2006) reported that the soybean-wheat (Triticum aestivum L.) succession provided total organic carbon $46 \%$ higher than corn-black oat (Avena strigosa Schreb.), though both successions produced the same quantity of plant residues, probably due to the rapid decomposition of soybean residues, which may have boosted wheat dry matter productivity (Weber \& Mielniczuk, 2009). It should be noted that nitrogen availability by legumes cultivated in summer can exceed the needs of plants cultivated as second crops (Weber \& Mielniczuk, 2009).

Mineral-associated carbon fraction, followed by fine particulate and medium particulate fractions, had higher total carbon and nitrogen (Figure 2). The highest carbon and nitrogen content verified in the more stable fraction, i.e., mineral-associated carbon, indicates a

Table 2. Carbon and nitrogen contents in bulk soil, under three cropping systems combined with seven crop sequences, under no-tillage ${ }^{(1)}$.

\begin{tabular}{|c|c|c|c|c|}
\hline \multirow[t]{2}{*}{ Second crops $(\mathrm{W})^{(2)}$} & \multicolumn{3}{|c|}{ Summer crops $(\mathrm{S})^{(3)}$} & \multirow[t]{2}{*}{ F-test } \\
\hline & Soybean/corn rotation & Corn monocropping & Soybean monocropping & \\
\hline \multicolumn{5}{|c|}{ Carbon content $\left(\mathrm{g} \mathrm{kg}^{-1}\right)$} \\
\hline Corn & $18.61 \mathrm{~A}$ & $12.30 \mathrm{Bc}$ & $19.75 \mathrm{Aa}$ & $28.87^{*}$ \\
\hline Sunflower & 18.38 & $14.54 \mathrm{bc}$ & $16.86 \mathrm{ab}$ & $6.71^{\mathrm{ns}}$ \\
\hline Oilseed radish & 16.50 & $16.31 \mathrm{ab}$ & $16.49 \mathrm{~b}$ & $0.19^{\text {ns }}$ \\
\hline Pearl millet & 16.49 & $17.02 \mathrm{ab}$ & $17.20 \mathrm{ab}$ & $0.25^{\mathrm{ns}}$ \\
\hline Pigeon pea & 16.03 & $19.01 \mathrm{a}$ & $18.60 \mathrm{ab}$ & $4.67^{\mathrm{ns}}$ \\
\hline Grain sorghum & 18.25 & $15.96 \mathrm{~b}$ & $17.69 \mathrm{ab}$ & $1.90^{\mathrm{ns}}$ \\
\hline Sun hemp & 18.44 & $18.93 \mathrm{a}$ & $18.48 \mathrm{ab}$ & $0.41^{\mathrm{ns}}$ \\
\hline F-test & $2.87^{\mathrm{ns}}$ & $9.36^{*}$ & $2.68^{*}$ & \\
\hline \multicolumn{5}{|c|}{ Nitrogen content $\left(\mathrm{g} \mathrm{kg}^{-1}\right)$} \\
\hline Corn & $1.57 \mathrm{~A}$ & $1.10 \mathrm{Bc}$ & $1.70 \mathrm{Aa}$ & $15.25^{*}$ \\
\hline Sunflower & 1.53 & $1.27 \mathrm{bc}$ & $1.43 \mathrm{~cd}$ & $2.79^{\text {ns }}$ \\
\hline Oilseed radish & 1.40 & $1.37 \mathrm{bc}$ & $1.40 \mathrm{~d}$ & $0.06^{\mathrm{ns}}$ \\
\hline Pearl millet & 1.53 & $1.50 \mathrm{ab}$ & $1.50 \mathrm{c}$ & $0.23^{\text {ns }}$ \\
\hline Pigeon pea & 1.63 & $1.68 \mathrm{a}$ & $1.53 \mathrm{bc}$ & $2.79^{\text {ns }}$ \\
\hline Grain sorghum & 1.53 & $1.33 b c$ & $1.43 \mathrm{~cd}$ & $3.59^{\text {ns }}$ \\
\hline Sun hemp & 1.57 & $1.67 \mathrm{a}$ & $1.60 \mathrm{bc}$ & $0.40^{\mathrm{ns}}$ \\
\hline F-test & $2.36^{\mathrm{ns}}$ & $5.93^{*}$ & $1.98^{*}$ & \\
\hline
\end{tabular}


strong organomineral relationship (Bayer et al., 2009), which is important for soil carbon sequestration.

Soybean/corn rotation and soybean monocropping were the cropping systems with the highest rate of carbon sequestration, especially with sun hemp as a second crop (Table 1). These results emphasize the importance of the input of large amounts of nitrogen by legume crops for a rapid increase in particulate carbon. Martins et al. (2012b) reported that this kind of input contributes to carbon sequestration in Oxisols in tropical regions. The benefits of sun hemp in the accumulation of soil carbon may be attributed to its low $\mathrm{C}: \mathrm{N}$ ratio, which favors increasing nitrogen availability, necessary for rapid residue processing into the particulate soil carbon fractions. The C:N ratio of sun hemp residues is equal to 23 , with the following amounts of nitrogen accumulated, released, and remaining: $110.1,89$, and $21.1 \mathrm{~g} \mathrm{~kg}^{-1}$, respectively (Marcelo et al., 2012b). The average rate of carbon sequestration for the crop sequences in the present study was of $0.63 \mathrm{Mg} \mathrm{ha}^{-1}$ per year, higher than the average of $0.35 \mathrm{Mg} \mathrm{ha}^{-1}$ per year found by Bayer et al. (2006), and lower than the one of $0.89 \mathrm{Mg} \mathrm{ha}^{-1} \mathrm{C}$ per year reported by Sá et al. (2013).

Corn monocropping with sorghum as a second crop increased the mean weight diameter of soil aggregates (Table 1). Physically, the roots of grasses contribute to soil aggregation by approaching soil mineral particles.

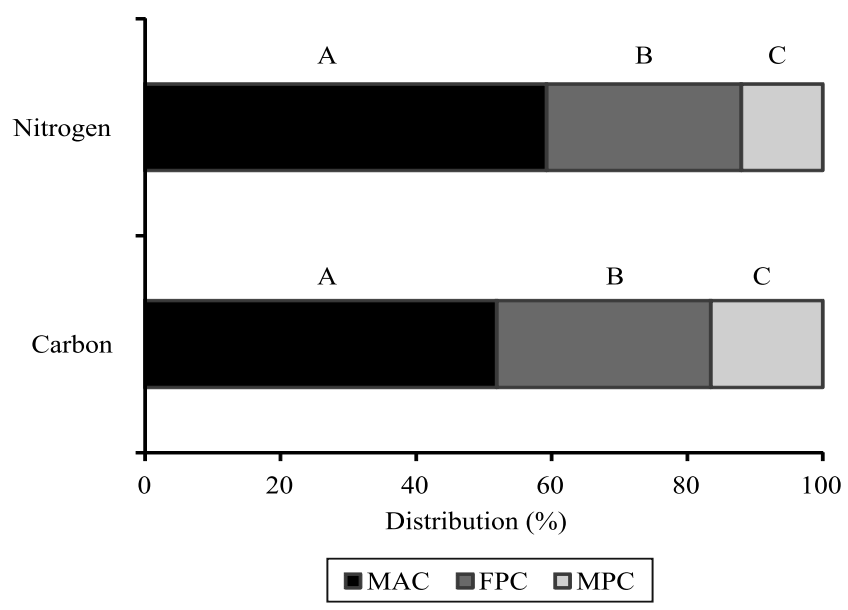

Figure 2. Distribution of carbon and nitrogen in mineral-associated carbon fraction (MAC), as well as in fine (FPC) and medium particulate carbon fractions (MPC). Means followed by equal letters do not differ by Tukey's test, at 5\% probability.
Chemically, they contribute by continuously releasing exudates into the soil. Moreover, the root system has high density and is constantly renovated, which contributes to the formation of macroaggregates (Six et al., 2002). These results agree with previous studies in the same experimental area, where grasses increased soil aggregation by increasing the contents of carbon and easily hydrolysable polysaccharides (Martins et al., 2009). Indirectly, the addition of larger amounts of polysaccharides and pentoses by grasses, particularly of arabinoses and xyloses, serve as a source of energy for microorganisms that act on soil aggregation (Martins et al., 2012a, 2013).

The mean weight diameter showed positive correlation $(\mathrm{r}=0.32)$ with carbon content in the fine particulate carbon fraction (Figure $3 \mathrm{~A}$ ). Although this fraction is commonly associated with microaggregation in Oxisols, the rather low correlation observed in the present study indicates that the high contents of oxides and hydroxides of $\mathrm{Al}$ and $\mathrm{Fe}$ in these soils have a greater role in the formation of microaggregates, which is crucial for fixing soil carbon (Six et al., 2002). The decomposition of particulate carbon produces more recalcitrant compounds, which act in the formation of microaggregates and stabilize carbon in the soil (Tisdall \& Oades, 1982; Conceição et al., 2013).

Soil total carbon was positively correlated $(\mathrm{r}=0.94)$ with total nitrogen (Figure $3 \mathrm{~B}$ ). The addition of nitrogen favored the accumulation of carbon, probably due to increasing microbial activity and biomass production by the subsequent crops. Nitrogen added by legumes is more effective to increase soil carbon than that added by mineral fertilizers, which favors the productivity of the following crops (Bayer et al., 2009; Conceição et al., 2013).

Total carbon was also positively correlated with the carbon content in the medium particulate $(\mathrm{r}=0.41)$ and fine particulate fractions $(\mathrm{r}=0.36)$, as shown in Figure $2 \mathrm{C}$ and $\mathrm{D}$. The correlation between particulate carbon and total carbon can be explained by the continuous addition of crop residue on soil surface. Carbon increases in soils under no-tillage occur, preferentially, in the particulate fraction, which is protected inside the soil aggregates. Previous studies in the same site reported a strong correlation $(\mathrm{r}=0.90)$ between particulate carbon and total carbon (Martins et al., 2012b).

Pesq. agropec. bras., Brasília, v.51, n.9, p.1652-1659, set. 2016 DOI: 10.1590/S0100-204X2016000900065 

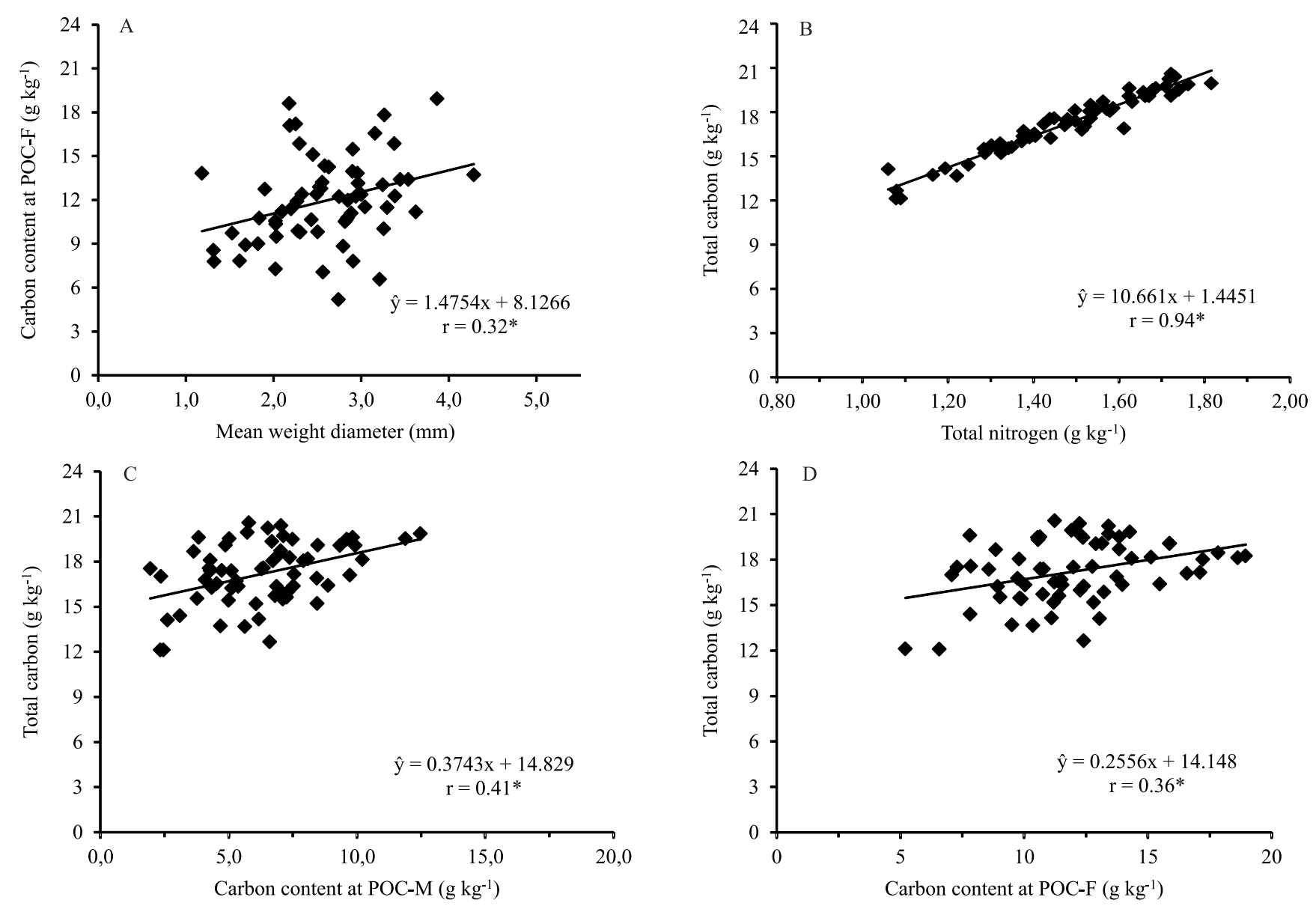

Figure 3. Regression analysis between: A, carbon content in fine particulate carbon fraction (POC-F, 250-53 $\mu \mathrm{m})$ and mean weight diameter; $\mathrm{B}$, total carbon and total nitrogen; $\mathrm{C}$, total carbon and carbon content in medium particulate carbon fraction (POC-M, 2,000-250 $\mu \mathrm{m})$; and D, total carbon and carbon content in POC-F $(\mathrm{n}=63)$.

\section{Conclusions}

1. The nitrogen added by soybean (Glycine max) in the summer raises carbon content in the soil medium particulate carbon fraction, and, indirectly, promotes soil aggregation.

2. Carbon stored in the medium particulate fraction increases soil aggregation.

3. Soybean, as a summer crop, and sun hemp (Crotalaria juncea), as a second crop, provide higher rates of carbon sequestration.

\section{References}

AMADO, T.J.C.; BAYER, C.; CONCEIÇÃO, P.C.; SPAGNOLLO, E.; CAMPOS, B.-H.C. de; VEIGA, M. da. Potential of carbon accumulation in no-till soils with intensive use and cover crops in southern Brazil. Journal of Environmental Quality, v.35, p.1599-1607, 2006. DOI: 10.2134/jeq2005.0233.
BAYER, C.; DIECKOW, J.; AMADO, T.J.C.; ELTZ, F.L.F.; VIEIRA, F.C.B. Cover crop effects increasing carbon storage in a subtropical no-till sandy Acrisol. Communications in Soil Science and Plant Analysis, v.40, p.1499-1511, 2009. DOI: 10.1080/00103620902820365.

BAYER, C.; MARTIN-NETO, L.; MIELNICZUK, J.; PAVINATO, A.; DIEKOW, J. Carbon sequestration in two Brazilian Cerrado soils under no-till. Soil and Tillage Research, v.86, p.237-245, 2006. DOI: 10.1016/j.still.2005.02.023.

BAYER, C.; MIELNICZUK, J. Dinâmica e função da matéria orgânica. In: SANTOS, G. de A.; SILVA, L.S. da; CANELLAS, L.P.; CAMARGO, F.A.O. (Ed.). Fundamentos da matéria orgânica do solo em ecossistemas tropicais e subtropicais. 2.ed. rev. e ampl. Porto Alegre: Metrópole, 2008. p.7-18.

CALEGARI, A.; HARGROVE, W.L.; RHEINHEIMER, D. dos S.; RALISCH, R.; TESSIER, D.; TOURDONNET, S. de; GUIMARÃES, M. de F. Impact of long-term no-tillage and cropping system management on soil organic carbon in an Oxisol: a model for sustainability. Agronomy Journal, v.100, p.10131019, 2008. DOI: 10.2134/agronj2007.0121. 
CONCEIÇÃO, P.C.; DIEKOW, J.; BAYER, C. Combined role of no-tillage and cropping systems in soil carbon stocks and stabilization. Soil and Tillage Research, v.129, p.40-47, 2013. DOI: $10.1016 /$ j.still.2013.01.006.

DIEKOW, J.; MIELNICZUK, J.; KNICKER, H.; BAYER, C.; DICK, D.P.; KÖGEL-KNABNER, I. Carbon and nitrogen stocks in physical fractions of a subtropical Acrisol as influenced by long-term no-till cropping systems and $\mathrm{N}$ fertilisation. Plant and Soil, v.268, p.319-328, 2005. DOI: 10.1007/s11104-004-0330-4.

ELLERT, B.H.; BETTANY, J.R. Calculation of organic matter and nutrients stored in soils under contrasting management regimes. Canadian Journal of Soil Science, v.75, p.529-538, 1995. DOI: 10.4141/cjss95-075.

GROSSMAN, R.B.; REINSCH, T.G. The solid phase: bulk density and linear extensibility. In: DANE, J.H.; TOPP, G.C. (Ed.). Methods of soil analysis: physical methods. Madison: Soil Science Society of America, 2002. Part 4, p.201-228.

HEINZMANN, F.X. Resíduos culturais de inverno e assimilação de nitrogênio por culturas de inverno. Pesquisa Agropecuária Brasileira, v.20, p.1021-1030, 1985.

KOUTIKA, L.S.; HAUSER, S.; HENROT, J. Soil organic matter assessment in natural regrowth, Pueraria phaseoloides and Mucuna pruriens fallow. Soil Biology and Biochemistry, v.33, p.1095-1101, 2001. DOI: 10.1016/S0038-0717(01)00015-3.

LAL, R. Climate change mitigation by managing the terrestrial biosphere. In: LAL, R.; LORENZ, K.; HÜTTL, R.F.; SCHNEIDER, B.U.; BRAUN, J. von. (Ed.). Recarbonization of the biosphere: ecosystems and the global carbon cycle. Netherlands: Springer, 2012. p.17-39. DOI: 10.1007/978-94-007-4159-1_2.

LAL, R. Soil carbon sequestration for sustaining agricultural production and improving the environment with particular reference to Brazil. Journal of Sustainable Agriculture, v.26, p.23-42, 2005. DOI: 10.1300/J064v26n04_04.

MARCELO, A.V.; CORÁ, J.E.; FERNANDES, C. Sequências de culturas em sistema de semeadura direta. I - Produção de matéria seca e acúmulo de nutrientes. Revista Brasileira de Ciência do Solo, v.36, p.1553-1567, 2012a. DOI: 10.1590/S010006832012000500020.

MARCELO, A.V.; CORÁ, J.E.; FERNANDES, C. Sequências de culturas em sistema de semeadura direta. II - Decomposição e liberação de nutrientes na entressafra. Revista Brasileira de Ciência do Solo, v.36, p.1568-1582, 2012b. DOI: 10.1590/S010006832012000500021.

MARCELO, A.V.; CORÁ, J.E.; FERNANDES, C.; MARTINS, M. dos R.; JORGE, R.F. Crop sequences in no-tillage system: effects on soil fertility and soybean, maize and rice yield. Revista Brasileira de Ciência do Solo, v.33, p.417-428, 2009. DOI: 10.1590/S0100-06832009000200019.

MARTINS, M. dos R.; ANGERS, D.A.; CORÁ, J.E. Carbohydrate composition and water-stable aggregation of an Oxisol as affected by crop sequence under no-till. Soil Science Society of America Journal, v.76, p.475-484, 2012a. DOI: 10.2136/sssaj2011.0110.
MARTINS, M. dos R.; CORA, J.E.; JORGE, R.F.; MARCELO, A.V. Crop type influences soil aggregation and organic matter under no-tillage. Soil and Tillage Research, v.104, p.22-29, 2009. DOI: 10.1016/j.still.2008.11.003.

MARTINS, M.R.; ANGERS, D.A.; CORÁ, J.E. Co-accumulation of microbial residues and particulate organic matter in the surface layer of a no-till Oxisol under different crops. Soil Biology and Biochemistry, v.50, p.208-213, 2012b. DOI: 10.1016/j. soilbio.2012.03.024.

MARTINS, M.R.; ANGERS, D.A.; CORÁ, J.E. Non-labile plant $\mathrm{C}$ contributes to long-lasting macroaggregation of an Oxisol. Soil Biology and Biochemistry, v.58, p.153-158, 2013. DOI: 10.1016/j. soilbio.2012.11.011.

SÁ, J.C. de M.; LAL, R. Stratification ratio of soil organic matter pools as an indicator of carbon sequestration in a tillage chronosequence on a Brazilian Oxisol. Soil and Tillage Research, v.103, p.46-56, 2009. DOI: 10.1016/j.still.2008.09.003.

SÁ, J.C. de M.; SÉGUY, L.; TIVET, F.; LAL, R.; BOUZINAC, S.; BORSZOWSKEI, P.R.; BRIEDIS, C.; SANTOS, J.B. dos; HARTMAN, D. da C.; BERTOLONI, C.G.; ROSA, J.; FRIEDRICH, T. Carbon depletion by plowing and its restoration by no-till cropping systems in Oxisols of subtropical and tropical agro-ecoregions in Brazil. Land Degradation and Development, v.26, p.531-543, 2013. DOI: 10.1002/ldr.2218.

SANTOS, H.G. dos; JACOMINE, P.K.T.; ANJOS, L.H.C. dos; OLIVEIRA, V.A. de; LUMBRERAS, J.F.; COELHO, M.R.; ALMEIDA, J.A. de; CUNHA, T.J.F.; OLIVEIRA, J.B. de. Sistema brasileiro de classificação de solos. 3.ed. rev. e ampl. Brasília: Embrapa, 2013. 353p.

SEO, J.-H.; MEISINGER, J.J.; LEE, H.-J. Recovery of nitrogen15-labeled hairy vetch and fertilizer applied to corn. Agronomy Journal, v.98, p.245-254, 2006. DOI: 10.2134/agronj2005.0013.

SILVA, A.P.; BABUJIA, L.C.; FRANCHINI, J.C.; SOUZA, R.A.; HUNGRIA, M. Microbial biomass under various soil- and crop-management systems in short- and long-term experiments in Brazil. Field Crops Research, v.119, p.20-26, 2010. DOI: 10.1016/j.fcr.2010.06.02.

SIX, J.; FELLER, C.; DENEF, K.; OGLE, S.M.; SÁ, J.C. de M.; ALBRECHT, A. Soil organic matter, biota and aggregation in temperate and tropical soils - effects of no-tillage. Agronomie, v.22, p.755-775, 2002. DOI: 10.1051/agro:2002043.

TISDALL, J.M.; OADES, J.M. Organic matter and water-stable aggregates in soil. Journal of Soil Science, v.33, p.141-163, 1982. DOI: 10.1111/j.1365-2389.1982.tb01755.x.

WEBER, M.A.; MIELNICZUK, J. Estoque e disponibilidade de nitrogênio no solo em experimento de longa duração. Revista Brasileira de Ciência do Solo, v.33, p.429-437, 2009. DOI: 10.1590/S0100-06832009000200020.

YODER, R.E. A direct method of aggregate analysis of soils and a study of the physical nature of erosion losses. Journal of the American Society of Agronomy, v.28, p.337-351, 1936. DOI: 10.2134/agronj1936.00021962002800050001x.

Received on August 31, 2015 and accepted on June 24, 2016

Pesq. agropec. bras., Brasília, v.51, n.9, p.1652-1659, set. 2016 DOI: 10.1590/S0100-204X2016000900065 